\title{
PENERAPAN METODE PEMBELAJARAN INQUIRY DALAM PENINGKATAN RASA INGIN TAHU DAN KREATIVITAS SISWA PADA MATERI KALOR DI SMA NEGERI 3 PADANGSIDIMPUAN
}

\author{
Nur Aisyah Harahap \\ Guru Fisika SMA Negeri 3 Padangsidimpuan \\ nur.aisyah12345@yahoo.com
}

DOI : 10.31604/ptk.v1i3.179-184

\begin{abstract}
One of the demands of the Curriculum for teachers in learning, using the learning models appropriate to the characteristics of the material and their students. However, the reality on the ground shows teachers generally use methods lectures are teachercentered and fewer teachers facilitate students to work in groups in learning. One form of the model that can enable students to work together in learning is modelInquiry. The purpose of this study was to describe the competence of physics students. This type of research is a research action class. The location of the research of SMA Negeri 3 Padangsidimpuan. The subject of research grade $X$ with a total of 29 students. The research was conducted by two cycle consists of four steps of research, namely planning, implementation, observation, and reflection. Research instrument consisting of a sheet of observation and tests the student's competence. The technique of data analysis was descriptive. Implementation research is held in even-numbered Annual semester Teaching 2013/2014. The results showed an increase in the competence of physics students. The results of the three cycles undertaken showed an increase in the percentage of students who achieve a minimum criterion. The percentage of students who complete learning increased from $36 \%$ in cycle I became the $88 \%$ in cycle III. The average value of student learning outcomes have also been increased from 66.88 on cycle I became 85.52 cycles III. Thus, it can be concluded the implementation model of inquiry can improve the competence of physics students of class X SMA Negeri 3 Padangsidimpuan.
\end{abstract}

Keywords: Learning Methods Of Inquiry, Curiosity, Creativity.

\begin{abstract}
Abstrak
Salah satu tuntutan Kurikulum bagi guru dalam pembelajaran, menggunakan modelmodel pembelajaran sesuai dengan karakteristik materi dan siswanya. Namun kenyataannya di lapangan menunjukkan guru umumnya menggunakan metode ceramah bersifat teacher centered dan guru masih kurang memfasilitasi siswa untuk bekerja kelompok di dalam pembelajaran. Salah satu bentuk model yang dapat mengaktifkan siswa bekerja sama dalam pembelajaran adalah model Inquiry. Tujuan penelitian ini adalah untuk mendeskripsikan kompetensi fisika siswa. Jenis penelitian adalah penelitian tindakan kelas. Lokasi penelitian SMA Negeri 3 Padangsidimpuan. Subyek penelitian siswa kelas X dengan jumlah 29 orang siswa. Penelitian dilakukan sebanyak dua siklus terdiri dari empat langkah penelitian yaitu perencanaan, pelaksanaan, observasi dan refleksi. Instrumen penelitian terdiri dari lembar observasi dan tes


PeTeKa (Jurnal Penelitian Tindakan Kelas dan Pengembangan Pembelajaran)

Vol 1 No 3 Tahun 2018 Hal 179-184

kompetensi siswa. Teknik analisis data adalah deskriptif. Pelaksanaan penelitian diadakan pada semester genap Tahuan Ajaran 2013/2014. Hasil penelitian menunjukkan terjadi peningkatan kompetensi fisika siswa. Hasil dari tiga siklus yang dilalui menunjukkan terjadi peningkatan persentase siswa yang mencapai Kriteria Ketuntasan Minimal (KKM). Persentase siswa yang tuntas belajar meningkat dari $36 \%$ pada siklus I menjadi $88 \%$ pada siklus III. Rata-rata nilai hasil belajar siswa juga sudah meningkat dari 66,88 pada siklus I menjadi 85,52 pada siklus III. Dengan demikian, dapat disimpulkan penerapan model inquiry dapat meningkatkan kompetensi fisika siswa kelas X SMA Negeri 3 Padangsidimpuan.

Kata Kunci: Metode Pembelajaran Inquiry, Rasa Ingin Tahu, Kreativitas.

\section{PENDAHULUAN}

Pendidikan merupakan jalinan hubungan yang harmonis antar berbagai unsur yang salah satunya terdiri dari guru, siswa, dan lingkungan sekolah ataupun lingkungan masyarakat. Peran guru sangat penting dalam membuat siswa dapat belajar secara efektif. Pemilihan metode pembelajaran yang tepat akan mempengaruhi kualitas proses belajar mengajar. Sangat penting untuk dapat menciptakan situasi pembelajaran yang menyenangkan dan efektif agar siswa dapat belajar secara optimal dan mampu meningkatkan kreativitasnya.

Suasana pembelajaran di kelas pada saat ini umumnya masih berpusat pada guru dan bersifat komunikasi satu arah (one way communication). Menurut Sanjaya (2006) dengan metode yang berpusat pada guru, siswa tidak terlibat aktif dalam belajar dan pada umumnya pembelajaran menjadi tidak menyenangkan. Dalam proses belajar fisika, permasalahan ini juga sering ditemui. Permasalahan lain, dalam pembelajaran fisika adalah kurangnya pelaksanaan praktikum untuk menunjang pembelajaran. Padahal praktikum yang terintegrasi dengan benar akan dapat meningkatkan rasa ingin tahu siswa dan pemahaman akan konsep fisika yang dipelajari. Siswa yang memiliki keingintahuan yang tinggi pada umumnya memiliki kreativitas yang kuat dalam belajar.

Berdasarkan data hasil observasi yang dilaksanakan pada siswa kelas $\mathrm{X}$ SMA Negeri 3 Padangsidimpuan sebagai berikut. Pertama, selama proses belajar mengajar berlangsung, siswa cenderung diam dan tidak menjawab pertanyaan-pertanyan yang diajukan guru, sehingga belum menunjukkan kelancaran siswa mengemukakan gagasan. Kedua, saat praktikum siswa cenderung main-main, tidak terfokus pada pengambilan data dan malas mengisi data hasil praktikum serta tidak mau memikirkan jawaban pertanyaanpertanyaan pada analisis data hasil praktikum, sehingga keaslian siswa membuat tanggapan belum dapat diidentifikasi. Ketiga, siswa cenderung menghafalkan satu jawaban yang benar, dan kemampuan siswa maupun guru dalam mencari alternatif jawaban dari masalah masih kurang, sehingga belum tampak keluwesan siswa memikirkan alternatif jawaban yang bervariasi. Keempat, sebagian besar siswa senang saat melakukan praktikum namun belum dapat mengaitkan hasil praktikum dengan materi yang sedang dibahas, menunjukkan bahwa keterperincian siswa mengaitkan konsep satu dengan lainnya perlu dilatih. Kelima, siswa kesulitan memahami 
konsep-konsep fisika serta kaitannya dengan permasalahan dalam penerapan konsep di kehidupan sehari-hari. Hal tersebut mengindikasikan bahwa kreativitas siswa dalam mengemukakan gagasan dan rasa ingin tahu siswa dalam belajar konsep fisika masih rendah.

Menurut Sagala (2005) metode pembelajaran ini sering juga dinamakan metode heuritic, yang berasal dari bahasa Yunani, yaitu heuriskein yang berarti saya menemukan. Sanjaya (2006) Metode Pembelajaran inquiry adalah rangkaian kegiatan pembelajaran yang menekankan pada proses berpikir secara kritis dan analitis untuk mencari dan menemukan sendiri jawaban dari suatu masalah yang dipertanyakan. Proses berpikir itu sendiri biasanya dilakukan melalui tanya jawab antara guru dan siswa.

Metode pembelajaran inquiry merupakan metode pembelajaran yang banyak dianjurkan oleh karena metode ini memiliki beberapa keunggulan (Roestiyah, 2001) (1) Metode pembelajaran inquiry merupakan metode pembelajaran yang menekankan kepada pengembangan aspek kognitif, afektif, dan psikomotorik secara seimbang, sehingga pembelajaran ini dianggap bermakna. (2) Metode pembelajaran inquiry dapat memberikan ruang kepada siswa untuk belajar sesuai dengan gaya belajar mereka. (3) Metode pembelajaran inquiry yang dianggap sesuai dengan perkembangan psikologi modern yang menganggap belajar adalah proses perubahan tingkah laku berkat adanya pengalaman. (4) Dapat melayani kebutuhan siswa yang memiliki kemampuan diatas rata-rata. Artinya, siswa yang memiliki kemampuan belajar bagus tidak akan terhambat oleh siswa yang lemah dalam belajar. (5) Mendorong siswa untuk berpikir dan bekerja atas inisiatifnya sendiri, bersikap objektif, jujur dan terbuka. (6) Mendorong siswa untuk berpikir intuitif dan merumuskan hipotesinya sendiri.

Peningkatan rasa ingin tahu yang terjadi tiap siklus sepenuhnya dipengaruhi oleh penerapan model pembelajaran inkuiri. Mengajar siswa bagaimana cara untuk belajar dan bagaimana mengembangkan rasa ingin tahu merupakan tujuan pendidik pada umumnya dan guru sains pada khususnya (Sadeh, 2007).

Susanto, (2012) mendefinisikan kreativitas sebagai kemampuan seseorang untuk melahirkan sesuatu yang baru, baik berupa gagasan maupun karya nyata, yang relatif berbeda dengan apa yang telah ada sebelumnya. Selanjutnya, menurut Torrance dalam Wardani (2011) mendefinisikan kreativitas sebagai proses merasakan dan mengamati adanya masalah, membuat dugaan, menilai dan menguji dugaan atau hipotesis, kemudian menganalisis, dan terakhir menyampaikan laporan hasil. Selanjutnya, Suratno (2009) mengemukakan bahwa kreativitas adalah kemampuan berpikir seseorang dalam menghasilkan gagasan baru yang efektif dan etis. Kreativitas selalu merujuk pada kompetensi seseorang untuk menemukan sesuatu yang belum pernah ada. Dengan demikian penulis menyimpulkan bahwa kreativitas adalah kemampuan seseorang untuk menggagas kemudian menemukan sesuatu yang baru dan belum pernah ada sebelumnya.

Bertitik tolak dari masalah yang akan diteliti secara umum, maka penelitian ini bertujuan untuk melihat peningkatan rasa ingin tahu siswa dan kreativitas siswa dalam belajar dengan penerapan metode pembelajaran inquiry pada materi pokok kalor di kelas $\mathrm{X}$ SMA Negeri 3 Padangsidimpuan. 
PeTeKa (Jurnal Penelitian Tindakan Kelas dan Pengembangan Pembelajaran)

Vol 1 No 3 Tahun 2018 Hal 179-184

\section{METODE}

Penelitian ini menggunakan model Penelitian Tindakan Kelas (PTK) dan di rencanakan menggunakan dua siklus. Penelitian terdiri dari empat komponen yaitu : Perencanaan, Tindakan, Observasi dan refleksi/evaluasi.

Penelitian akan dilaksanakan di SMA Negeri 3 Padangsidimpuan. Bertempat di Jalan Perintis Kemerdekaan No 54 Padangsidimpuan Selatan. Penelitian akan dilaksanakan pada semester genap dari januari sampai dengan pebruari 2014 memakan waktu selama 3 kali pertemuan atau 6 Jam Pelajaran. Subjek penelitian ini adalah rasa ingin tahu siswa dalam serta kreativitas siswa pada materi pokok kalor di kelas $\mathrm{X}^{4}$ SMA Negeri 3 Padangsidimpuan dengan jumlah siswa 30 orang.

Tim peneliti direncanakan berjumlah 2 orang terdiri dari guru fisika satu orang sebagai ketua dan pelaksana tunggal dan satu orang anggota penelitian. Peneliti bertugas melaksanakan penelitian mulai dari perencanaan sampai laporan. Sedang anggota peneliti bertugas sebagai pemantau yaitu menggumpulkan data penelitian baik melalui wawancara maupun observasi.

\section{HASIL DAN PEMBAHASAN}

\section{Deskripsi Data Hasil Belajar kognitif Siswa Siklus I}

Data tentang hasil belajar kognitif siswa pada siklus I diperoleh dengan mengadakan tes tertulis yang diikuti oleh 25 orang siswa dengan jumlah soal 5 buah berbentuk uraian. Data ini digunakan untuk mengetahui tingkat penguasaan siswa terhadap materi yang telah dipelajari selama siklus I.
Tabel 1: Persentase Ketuntasan Hasil Belajar Kognitif Siswa Siklus I

\begin{tabular}{ccccl}
\hline \multicolumn{3}{c}{ Tuntas } & \multicolumn{3}{c}{ Tidak Tuntas } & Keterangan \\
f & $\boldsymbol{\%}$ & f & $\boldsymbol{\%}$ & \\
\hline 9 & 36 & 16 & 64 & $\begin{array}{l}\text { Rata-rata } \\
\text { nilai } 66,88\end{array}$ \\
\hline
\end{tabular}

Dapat dilihat bahwa, dari 25 orang siswa, hanya 9 orang (40\%) yang sudah bernilai sama atau di atas KKM yaitu 70, sisanya 16 orang (60\%) masih bernilai di bawah KKM. Rata-rata nilai sebesar 66,88 masih dibawah KKM 70. Persentase ketuntasan siswa masih jauh dibawah $75 \%$.

Salah satu permasalahan yang ditemui di kelas sebelum tindakan dilaksanakan adalah rendahnya hasil belajar kognitif siswa. Setelah tindakan pada siklus I dilaksanakan dengan metode pembelajara inquiry, nilai ratarata kognitif siswa 66,88 dengan KKM 70. Persentase siswa yang tuntas belajar hanya $36 \%$. Persentase tersebut bisa dikatakan masih dibawah standar minimal yaitu $75 \%$. Diharapkan dengan dilaksanakan dengan metode pembelajara inquiry dapat meningkatkan hasil belajar kognitif siswa, karena dengan pembelajaran ini, siswa sudah mulai terlibat langsung proses penemuan, Sebagian dari mereka juga sudah mau bertanya jika ada materi yang tidak mereka pahami, dengan memelihara rasa ingin tahu lalu mengujinya dengan cara berbuat sehingga ditemukannya konsep akan lebih cepat pahamnya dan lebih lama tinggalnya konsep tersebut di dalam ingatan sehingga akan berimbas pada peningkatan hasil belajar. 


\section{Deskripsi Data Hasil Belajar kognitif Siswa Siklus II}

Data tentang hasil belajar kognitif siswa pada siklus II diperoleh dengan mengadakan tes tertulis yang diikuti oleh 25 orang siswa dengan jumlah soal 5 buah berbentuk uraian. Data ini digunakan untuk mengetahui tingkat penguasaan siswa terhadap materi yang telah dipelajari selama siklus II.

Tabel 2: Persentase Ketuntasan Hasil Belajar Kognitif Siswa Siklus II

\begin{tabular}{|c|c|c|c|}
\hline \multicolumn{2}{|c|}{ Tuntas } & \multirow{2}{*}{\multicolumn{2}{|c|}{$\begin{array}{l}\text { Tidak Tuntas Keterangan } \\
\text { f } \%\end{array}$}} \\
\hline f & $\%$ & & \\
\hline 17 & 68 & 32 & $\begin{array}{l}\text { Rata-rata } \\
\text { nilai } 72,64\end{array}$ \\
\hline
\end{tabular}

Dapat dilihat bahwa, dari 25 orang siswa, 17 orang $(68 \%)$ sudah bernilai sama atau di atas KKM yaitu 70 , sisanya 8 orang (32\%) masih bernilai di bawah KKM. Rata-rata nilai sebesar 72,64 sudah melebihi KKM 70. Kalau dilihat dari hasil belajar siklus I, pada siklus II ini jumlah siswa yang tuntas sudah mengalami peningkatan dari $9(36 \%)$ orang menjadi $17(68 \%)$ orang. Sesuai dengan indikator keberhasilan peningkatan hasil belajar yang ditetapkan pada penelitian ini yaitu $75 \%$ siswa yang memperoleh nilai tuntas belajar belum tercapai, maka dapat dikatakan tindakan yang dilakukan pada siklus II belum menyelesaikanpermasalahan di kelas yang di teliti, untuk itu perlu dilakukan tindak lanjutan dengan memperbaiki hal-hal yang masih belum berjalan menurut semestinya.

\section{Perkembangan Hasil Belajar kognitif Siswa dari Siklus I dan II}

Untuk melihat peningkatan hasil belajar kognitif siswa tiap siklus, maka diadakan analisis data.

Tabel 3: Persentase Perkembangan Hasil Belajar Kognitif Siswa dari Siklus I, II, III

\begin{tabular}{|c|c|c|c|c|c|}
\hline \multirow[t]{2}{*}{ Siklus } & \multicolumn{2}{|c|}{ Tuntas } & \multicolumn{2}{|c|}{$\begin{array}{l}\text { Tidak } \\
\text { Tuntas }\end{array}$} & \multirow[t]{2}{*}{ Keterangan } \\
\hline & f & $\%$ & f & $\%$ & \\
\hline I & 9 & 36 & 16 & 64 & $\begin{array}{c}\text { Rata-rata } \\
\text { nilai } 66,88\end{array}$ \\
\hline II & 17 & 68 & 8 & 32 & $\begin{array}{c}\text { Rata-rata } \\
\text { nilai } 72,64\end{array}$ \\
\hline III & 22 & 88 & 3 & 12 & $\begin{array}{c}\text { Rata-rata } \\
\text { nilai } 85,52\end{array}$ \\
\hline
\end{tabular}

Bahwa analisis evaluasi belajar kognitif setelah siklus I, siklus II dan siklus III dilaksanakan terlihat bahwa terjadi peningkatan banyaknya siswa yang sudah mencapai KKM yang ditetapkan yaitu $9(36 \%)$ orang pada siklus I, menjadi $17(68 \%)$ orang pada siklus II, dan meningkat lagi menjadi $22(88 \%)$ orang pada siklus III. Artinya perlakuan yang diberikan pada siklus III berhasil meningkatkan kompetensi siswa hingga mencapai KKM yang telah ditetapkan sebagai indikator keberhasilan dalam penelitian ini.

\section{SIMPULAN}

Dari pelaksanaan tindakan mulai dari Siklus I sampai Siklus II didapati kenyataan bahwa pembelajaran dengan melakukan dengan metode pembelajara inquiry untuk konsep suhu dan kalor telah memberikan dampak positif terhadap peningkatan kompetensi siswa dalam belajar. Sesuai dengan indikator keberhasilan siswa dikatakan sudah tuntas jika KKM telah tercapai dan $75 \%$ dari siswa sudah tuntas, maka dapat dikatakan bahwa tindakan yang 
PeTeKa (Jurnal Penelitian Tindakan Kelas dan Pengembangan Pembelajaran)

Vol 1 No 3 Tahun 2018 Hal 179-184

dilakukan pada siklus II sudah dapat menyelesaikan permasalahan dikelas peneliti. Dari data hasil analisis evaluasi hasil belajar setelah setiap siklus terlihat adanya peningkatan jumlah siswa yang mencapai KKM yang telah ditetapkan yaitu dari 9 orang (36\%) pada siklus I, 17 orang $(68 \%)$ pada siklus II, menjadi 22 orang $(88 \%)$ pada akhir.

\section{DAFTAR PUSTAKA}

Roestiyah, N. K., 2001. Strategi Belajar Mengajar. Jakarta: Rineka Cipta.

Sadeh, Z. A. 2007. Curiosity and Open Inquiry Learning. Journal of Biologi Education 41(4).

Sagala, S. 2005. Konsep dan Makna Pembelajaran Untuk Membantu Memecahkan Problematika
Belajar dan Mengajar. Bandung: Alfabeta.

Sanjaya, W. 2006. "Strategi Pembelajaran Berorientasi Standar Proses Pendidikan”. Bandung: Kencana.

Suratno, T. 2009. Pengembangan Kreativitas Siswa dalam Pembelajaran Sains di Sekolah Dasar. Jurnal Pendidikan Dasar Nomor 12.

Susanto, A. 2013. Teori Belajar dan Pembelajaran di Sekolah Dasar. Jakarta: Prenadamedia Group.

Wardani, N. S. 2011. Upaya Meningkatkan Kreativitas Siswa dalam Pembelajaran IPS SD Melalui Diskusi Kelompok. Jurnal Widya Sari 13(1). 